\title{
I. MINERALOGY OF THE SEDIMENTARY SECTIONS ENCOUNTERED ON LEG 55 (SITES 430 THROUGH 433), BASED ON X-RAY DIFFRACTOMETRY
}

\author{
Ulrich Mann and German Müller, Institut für Sedimentforschung, Universität Heidelberg
}

\section{INTRODUCTION}

On Leg 55, cores were taken from three seamounts in the Emperor seamount chain: Ōjin, Nintoku, and Suiko Seamounts. At the drilling sites the water depth was 1300 to 1700 meters; the maximum thickness of the sediment column was 180 meters at Site 433 .

\section{METHODS}

The methods used are as we have described them in the Initial Reports of the Deep Sea Drilling Project for Legs 51, 52, 53 (Part 2: Sites 417 and 418) (in press, pp. 721-730). The scheme of estimation is depicted in Table 1. In addition, the amounts of amorphous constituents were estimated by measuring the extent of diffuse scattering. Factors for bulk mineralogy and clay mineralogy are presented in Tables 2 and 3.

\section{RESULTS}

The results of X-ray analyses are given in Table 4 and Figures 1 and 2. The sediments fall into two main groups: carbonate-rich (= deficient in clay) and carbonate-deficient sediments ( $=$ rich in clay). Calcite is nearly

TABLE 1

Flow Scheme of Semiquantitative Analyses of Bulk Composition of Sediments from Leg 55

\begin{tabular}{ll}
\hline \multicolumn{2}{c}{ BULK SAMPLE } \\
$\begin{array}{ll}\text { Amorphous Constituents } \\
\text { Carbonate Content }\end{array}$ & $\begin{array}{l}\text { Extent of Diffuse Scattering } \\
\text { Gon-Clay Minerals } \\
\text { Clay Minerals }\end{array}$ \\
$\begin{array}{ll}\text { Relative Compositiol Determination } \\
\text { Clay Minerals }\end{array}$ & $\begin{array}{l}\text { Fraction }<2 \mu \mathrm{m} \text { Smear Slide } \\
\text { Peak Area } \times \text { Factor (Table 3) }\end{array}$ \\
\hline
\end{tabular}

TABLE 2

Factors for Bulk Mineralogy

\begin{tabular}{lccc}
\hline \multicolumn{3}{c}{ Peak } \\
Mineral & $2 \theta\left({ }^{\circ}\right)$ & d (in $\AA)$ & Factor \\
\hline Quartz & 26.7 & 3.34 & 1.3 \\
Feldspar & $27.4-28.0$ & $3.25-3.18$ & 2.0 \\
Phillipsite & 12.3 & 7.2 & $4.0 ?$ \\
Apatite & 32.2 & 2.78 & 3.0 \\
Barite & 25.9 & 3.44 & 2.0 \\
Manganite & 26.2 & 3.40 & 2.0 \\
Pyrolusite & 28.3 & 3.15 & 2.0 \\
\hline
\end{tabular}

TABLE 3

Factors for Clay Mineralogy

\begin{tabular}{lrrc}
\hline \multicolumn{4}{c}{ Peak } \\
Mineral & $2 \theta\left(^{\circ}\right)$ & $\mathrm{d}($ in $\AA$ ) & Factor \\
\hline Smectite & 5.2 & 17.0 & 1 \\
Chlorite & 12.3 & 7.2 & 2 \\
Illite & 8.8 & 10.0 & 4 \\
Kaolinite & 12.3 & 7.2 & 2 \\
\hline
\end{tabular}

always the only carbonate mineral. For the clay minerals, smectite and illite are the alternately predominant clay minerals. Certain cores have relatively high amounts of amorphous material.

The data for Sites 430, 431, and 432 are sparse. At Site 433, we have divided the section into five units:

1) In the first unit above basement, the carbonate content is 60 per cent on the average, and consists mainly of calcite with some Mn-calcite. The feldspar content varies from 3 to 20 per cent, and may indicate varying amounts of volcanic components. Small amounts of smectite are present.

2) The second unit includes calcarenites with carbonate contents between 90 and 100 per cent. Calcite is the only carbonate component.

3) Clayey calcareous mud with 30 to 40 per cent clay minerals occurs in the third unit. Illite and, in the uppermost samples of this unit, barite and apatite are present.

4) This unit is made up of a siliceous calcareous mud. The amount of calcite varies from 20 to 90 per cent, depending on the amounts of diatoms and nannofossils.

5) The uppermost unit is also made up of calcareous mud. In contrast to the Fourth unit, this unit contains larger amounts of quartz, feldspar, and chlorite. In addition, there are Mn-rich minerals such as pyrolusite, Mn-calcite, and manganite (?). High percentages of amorphous components ( $\mathrm{Fe}$ - and $\mathrm{Mn}$-oxides ?) are also present in this unit.

\section{ACKNOWLEDGMENTS}

Thanks are due the German Research Association (DFG), which kindly provided financial assistance to carry out this investigation. Mr. S. Bucak aided us in performing the X-ray analyses. Mr. U. Kästner carefully provided the drawings in this report. 
TABLE 4

X-Ray Mineralogical Analyses, Leg 55

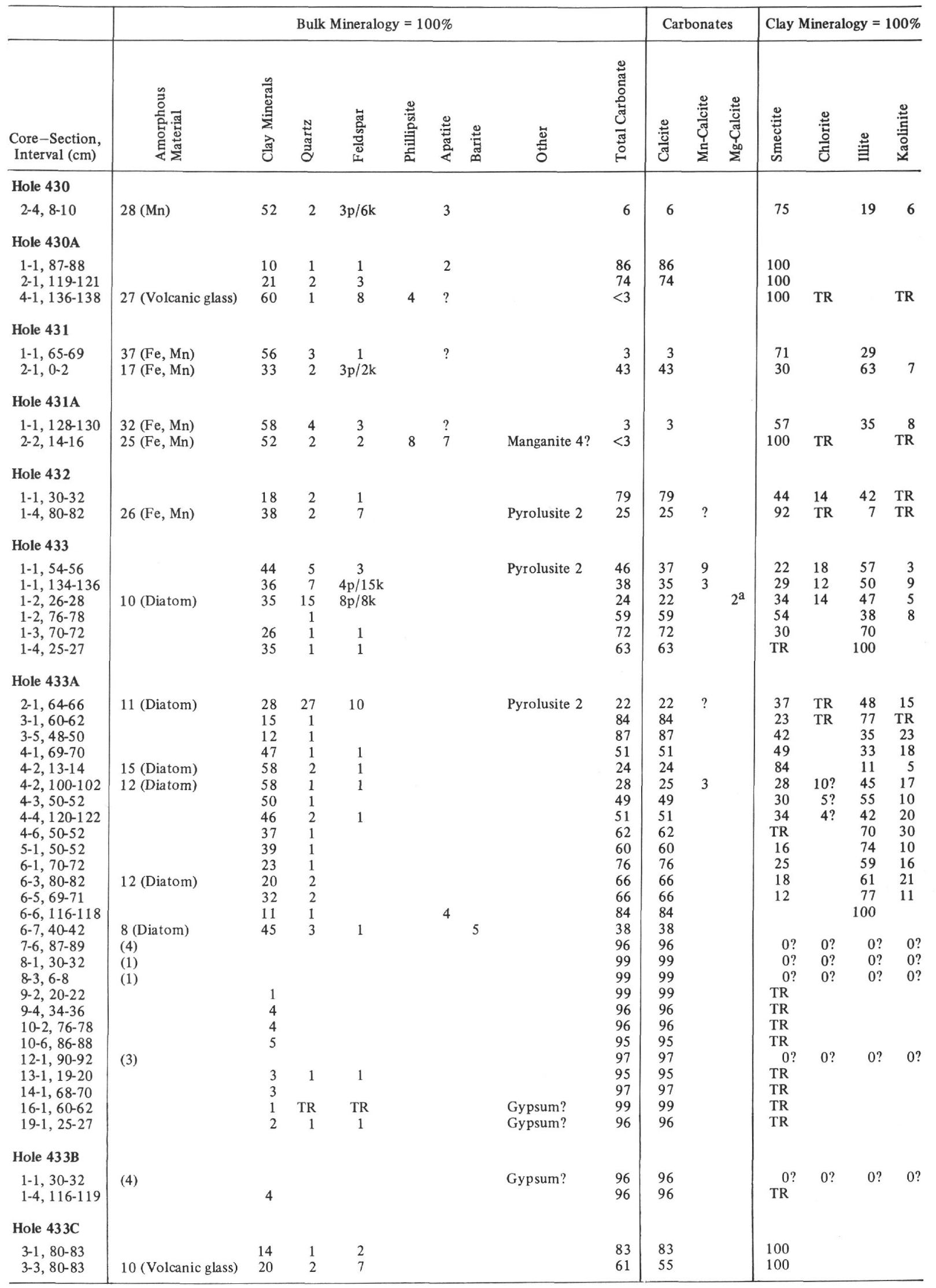

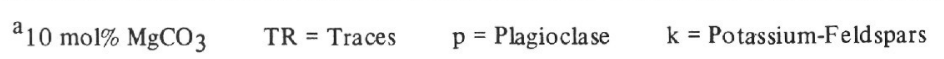


SITE 430

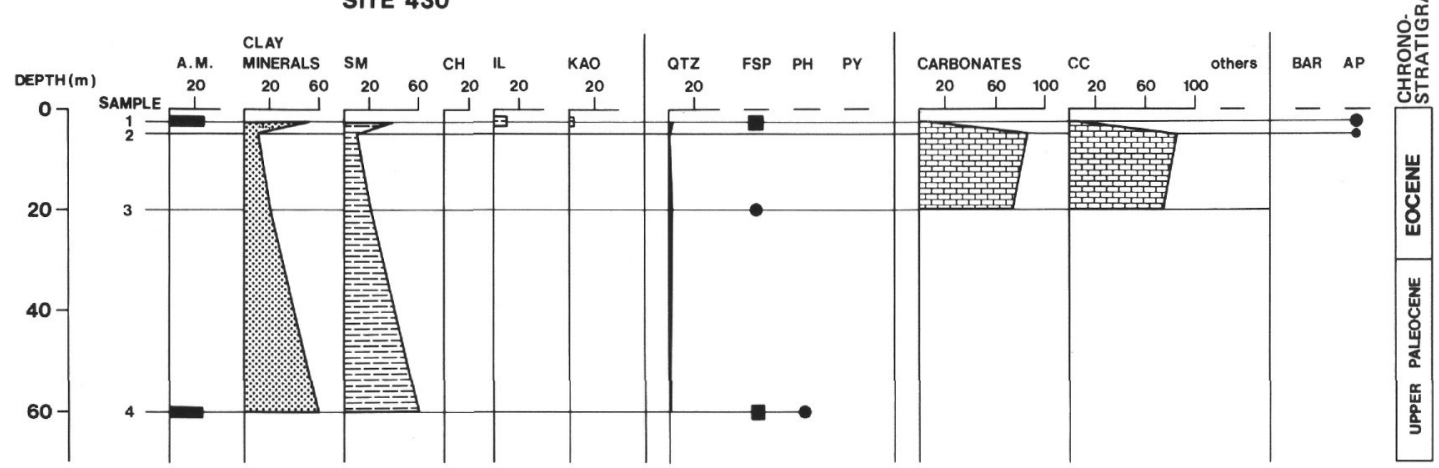

SITE 431
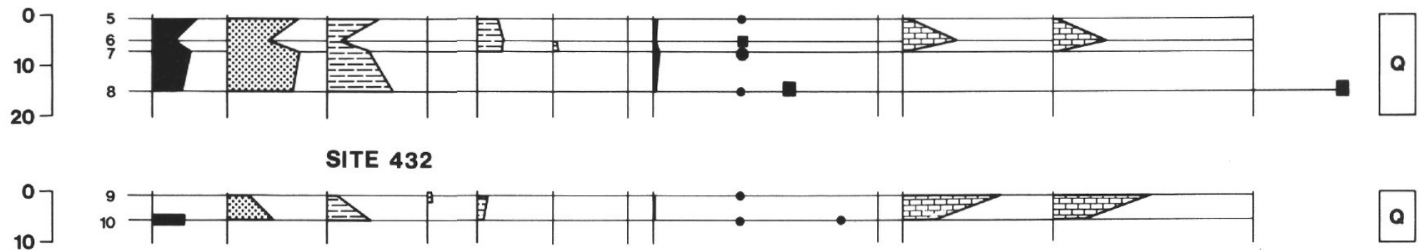

$a$

ABREVIATIONS

SM - SMECTITE

$\mathrm{CH}$ - CHLOAITE

IL - ILITE

KAO - KAOLMUTE

CC - CALCITE

Mn-CC - mangano - CALCITE

Mg-CC - MAGNEBIAN - CALCITE

OTZ - QUARTZ

FSP - FELDSPAR

PH - PHILLIPSITE

PY - PYROLUSITE

BAA - BARITE

ap - apatite

A.M. - AMORPHOUS MATERIN

Figure 1. Bulk Mineralogy and Clay Mineralogy, Sites 430, 431, 432.

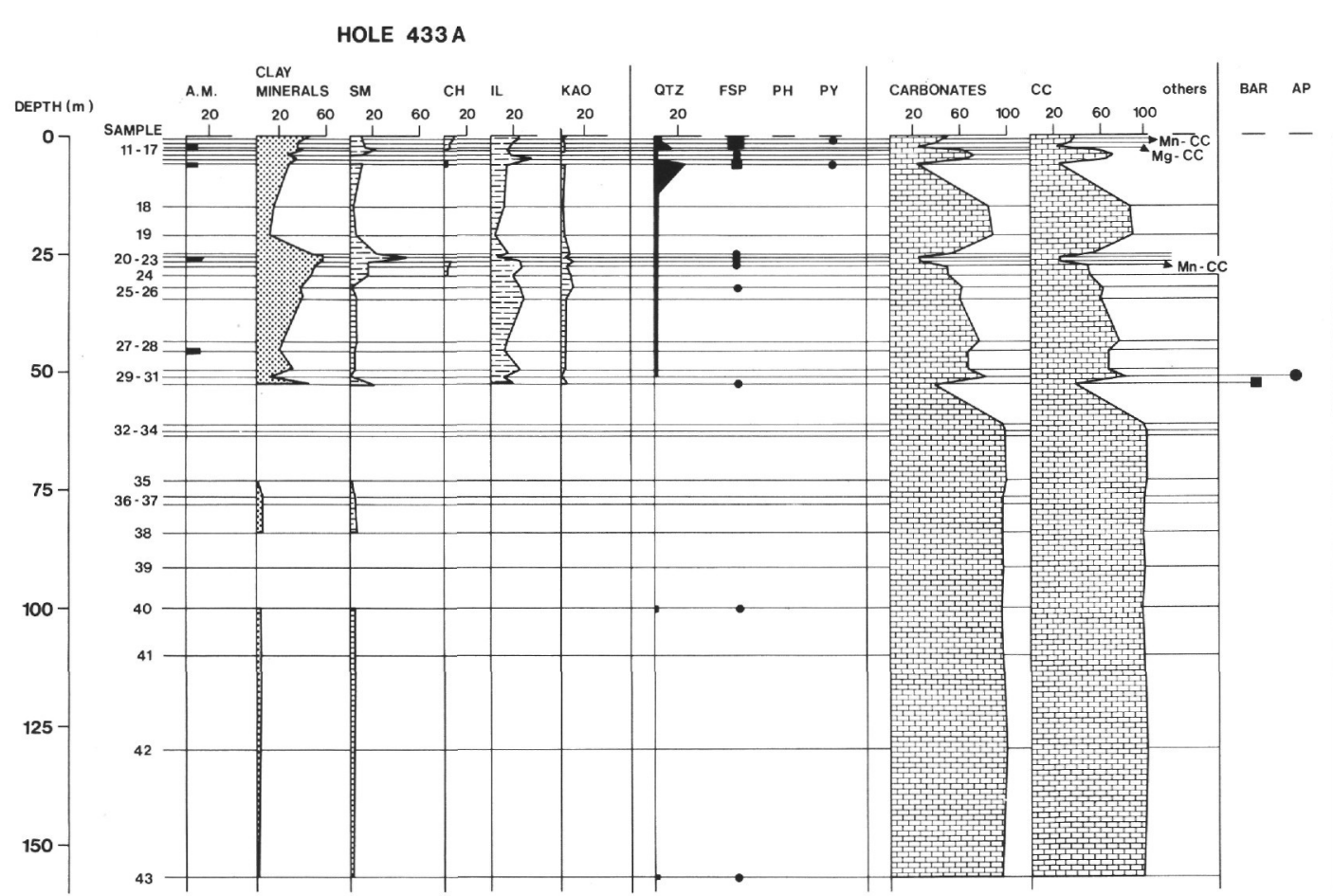

HOLE 433B

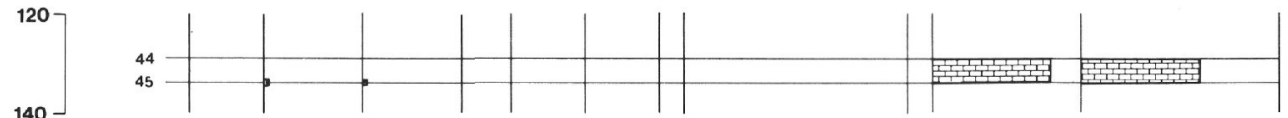

HOLE $433 \mathrm{C}$
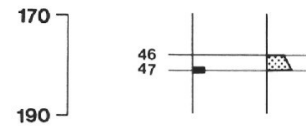

\section{1}

190

Figure 2. Bulk Mineralogy and Clay Mineralogy, Site 433.
ABREVIATIONS

SM - SMECTITE

$\mathrm{CH}-$ CHLORITE

KAO - KAOLINITE

CC - CALCITE

Mn-CC - MANGano - CALCITE

Mg-CC - MAGNESIAN - CALCITE

QTZ - QUARTZ

FSP - FELDSPAR

PH - PHILLIPSITE

PY - PYROLUSITE

BAR - BARITE

AP - apatite

A.M. - AMORPHOUS MATERIAL 